\title{
Corneal endothelial rejection after penetrating keratoplasty treated with intravenous and topic corticosteroid. One year follow up
}

\author{
Tratamento da rejeição endotelial pós-ceratoplastia penetrante \\ através da associação do pulso de metilprednisolona intravenosa \\ com acetato de prednisolona tópico. Seguimento de um ano
}

Ricardo Yuji Abe', Lívia Maria Dias Freire', Rosane Silvestre Castro', Rodrigo Pessoa Cavalcanti Lira', Carlos Eduardo Leite Arieta ${ }^{1}$

\begin{abstract}
Objective: To analyze the recovery of visual acuity (VA) and graft survival after first episode of endothelial rejection in penetrating keratoplasty (PKP) treated with intravenous (IV) and topic corticosteroid. Methods: Interventional, prospective, non-comparative case series study evolving 32 PKP patients in one year follow up, who presented first episode of corneal endothelial rejection. The patients were submitted to $500 \mathrm{mg} I V$ injection of methylprednisolone in association with topical prednisolone. Main outcome measures included VA recovery and corneal edema regression. Second outcome included new rejections and graft failure. Multivariate analysis techniques were used to estimate rates of graft outcome events and the impact of risk factors. Results: A total of 32 eyes from 32 patients (13 male and 19 female) were included in the study. The mean VA (in number of letters) before rejection was 48 (22 to 88 letters). Patients treated within 7 days or less of initial symptoms had better VA recovery, corneal edema regression and less graft failure $(p<0.001)$. Patients with previous ocular surgery had worse VA recovery and more graft failure $(p<0.047)$. Conclusion: The association between the other risk factors and the outcomes did not reach statistical significance in the multivariate model because of the small numbers of patients. Methylprednisolone in association with topical prednisolone is an alternative treatment for graft rejection. Our study showed that patients treated within 7 days of symptoms and no previous anterior segment surgery had better visual outcome and graft survival after treatment.
\end{abstract}

Keywords: Keratoplasty, penetrating; Graft rejection; Adrenal cortex hormones; Risk factors; Methylprednisolone/administration \& dosage; Methylprednisolone/therapeutic use; Treatment outcome

\section{RESUMO}

Objetivo: Analisar a recuperação da acuidade visual (AV) e sobrevivência do enxerto após primeiro episódio de rejeição endotelial em ceratoplastia penetrante (PK) em pacientes submetidos ao corticóide intravenoso (IV) associado ao tópico. Métodos: Estudo descritivo, prospectivo, tipo série de casos envolvendo 32 pacientes com PK tratados com 2 doses de 500mg de metilprednisolona IV (com intervalo de 1 semana) associado ao acetato de prednisolona $1 \%$. O parâmetro principal analisado foi a recuperação da AV e a regressão do edema corneano. O parâmetro secundário utilizado foi a recorrência das rejeições e a falência do enxerto. Resultados: Um total de 32 olhos de 32 pacientes foram incluídos no estudo (13 homens e 19 mulheres). A média da AV (em número de letras) foi 48. Pacientes tratados dentro de 7 dias ou menos após o surgimento dos sintomas apresentaram melhor recuperação da $\mathrm{AV}$ e menor falência do enxerto $(\mathrm{p}<0,001)$. Pacientes com antecedente de cirurgia ocular anterior à PK apresentaram pior recuperação da AV e maior índice de falência do enxerto. Conclusão: A associação entre os outros fatores de risco não atingiram significância estatística devido ao baixo número de pacientes do estudo. A metilprednisolona IV em associação com a prednisolona tópica pode ser uma alternativa para o tratamento da rejeição endotelial do enxerto. Nossos resultados sugerem que pacientes tratados dentro de 7 dias do início dos sintomas e a ausência de cirurgia ocular prévia apresentam melhor recuperação da AV e melhor sobrevivência do enxerto.

Descritores: Ceratoplastia penetrante/quimioterapia; Rejeição de enxerto; Corticosteróides; Fatores de risco; Metilprednisolona/ administração \& dosagem; Metilprednisolona/uso terapêutico; Resultado de tratamento

1.Department of Ophthalmoloy at the Hospital das Clínicas, Universidade Estadual de Campinas (UNICAMP) - Campinas (SP), Brazil; Study carried out at Department of Ophthalmology at the Hospital das Clínicas - Universidade Estadual de Campinas (UNICAMP) -

Campinas (SP), Brazil.

The authors declare no conflicts of interest

Recebido para publicação em: 23/7/2012 - Aceito para publicação em: 14/10/2012 


\section{INTRODUCTION}

D espite the exciting progress in corneal surgery, PK remains the most common form of corneal transplantation in the world at present, and although PK may diminish in importance in the future, it will remain the default or procedure of choice for some eyes ${ }^{(1)}$. The mean 5year survival according to the Australian Corneal Graft Registry is $73 \%$ and $31 \%$ of all failures are due to rejection ${ }^{(2)}$. The Singapore Corneal Transplant Study (SCTS) report $85 \%$ of graft survival in 10 years, in the absence of any postoperative risk factor. A lower graft survival (34\% at 10 years) was reported in presence of one postoperative risk factor, including infection, rejection, disease recurrence, eyelid or glaucoma surgery, or a repeat $\operatorname{graft}^{(3)}$. Although the preoperative risk factors for graft failure cannot be modified, the prevention or early detection of postoperative risk factors for graft failure may be important for prolonging graft survival. The risk factors for graft survival can be divided into recipient, donor, and postoperative risk factors. Recipient diagnosis is the most important preoperative risk factor, with grafts for keratoconus having the best survival rate, and grafts for endothelial disease, corneal opacity, and ipsilateral graft failure having a worse survival rate and survival also is worsened by active or previous intraocular inflammation or ocular hypertension ${ }^{(4)}$. After surgery, allograft rejection consistently has been found to be a leading cause of graft failure and effective treatment of corneal graft rejection is therefore vital. Although corticosteroids were the mainstay of treatment of corneal graft rejection, there are no consensus on optimal methods of administration, dosage, or treatment duration ${ }^{(5,6)}$. Evidence available so far suggests a beneficial role of intravenous (i.v.) methylprednisolone when combined with topical steroids over frequent topical steroids alone, and also over oral steroids in combination with topical steroids in selected cases ${ }^{(7)}$. The purpose of this study was to assess the efficacy of treating corneal endothelial allograft rejection with a double pulse of $500 \mathrm{mg}$ i.v. methylprednisolone and topical $1 \%$ prednisolone acetate and correlate the findings with the recipient, donor, and postoperative risk factors.

\section{Methods}

\section{Patient eligibility}

In this interventional, prospective, non-comparative case series study, 32 patients who underwent penetrating keratoplasty (with single suture technique) were enrolled. We did not exclude patients with ocular surgery prior to PK. The study was conducted from January 2010 through December 2010 in the Department of Ophthalmology at the Hospital das Clínicas State University of Campinas. All patients were engaged in an informed consent process before any study procedures were carried out. The study complied with the tenets of the Declaration of Helsinki and was approved by the State University of Campinas Ethical Committee. Patients were included if they presented with their first episode of corneal transplant endothelial rejection. Corneal graft rejection was defined as the appearance of one or more of the following: an endothelial rejection line, new keratic precipitates, anterior chamber cells, and/ or corneal edema in the donor graft not previously noted. The medical records of the eligible patients were reviewed and relevant demographic and clinical data such as surgical procedure and information about postoperative follow up were considered for their association with the graft outcome.

\section{Study medication}

Eyes that developed rejection were treated 2 pulses of $500 \mathrm{mg}$ i.v. Methylprednisolone (Solu-Medrol® Pfizer), with one week interval associated with topical corticosteroid (Predforte ®- prednisolone acetate ophthalmic suspension 1\% Allergan). The topical corticosteroid was used hourly (1/1 hour) for 1 week. After 1 week, patients were treated with topical prednisolone acetate $1.0 \%$ every 2 hours ( $2 / 2$ hours) for 2 more weeks, after which therapy was slowly tapered over 6 months. (The average corticosteroid regimen was as follows: 8 drops per 24 hours for 2 weeks, 6 drops per 24 hours for 2 weeks, 5 drops per 24 hours for 2 weeks, 4 drops per 24 hours for 1 month, 3 drops per 24 hours for 3 months, 2 drops per 24 hours for 3 months, and then 1 drop per 24 hours for 3 months.)

\section{Examination}

All patients underwent complete ophthalmological examination , including ETDRS best-corrected visual acuity (BCVA) testing, intraocular pressure measured with an applanation tonometer, slit-lamp examination, and corneal epithelial damage using the fluorescein staining test. Follow-up examinations were performed weekly during the first month after the rejection episode, and monthly during the next 5 months and trimestral during the following 6 months. The ETDRS chart was used to determine the BCVA, and decimal values were converted to their logarithm for statistical analysis. Corneal edema was graded by visual slit-lamp inspection according to a corneal clarity score ${ }^{(8)}$ with the following ratings: 1 - clear cornea., 2 - diffuse corneal edema with relative clarity to visualize underlying structures, 3 - relatively opaque cornea with some visualization of underlying structures and 4 - very opaque cornea, difficult to visualize underlying structures.

\section{Outcome measure}

Main outcome measures included BCVA before treatment in comparison to the most recent follow-up and corneal edema regression. Second outcome included new rejections and graft failure during follow up. The criteria for graft failure were irreversible graft stromal edema and corneal opacification (within one year of follow up).

\section{Statistical analysis}

In order to estimate rates of graft outcome events and the impact of risk factors we used the SPSS for Windows (version 19, IBM). T Student and qui-square test were used for the variables. Values $\mathrm{p}<0,05$ was considered statistically significant.

\section{ResULTS}

\section{Demographic and baseline data}

Between january 2010 and december 2010, a total of 32 eyes from 32 patients ( 13 male and 19 female) with mean age $48.78+/$ - 19.4 years were included in the study. The primary preoperative diagnoses for the 32 eyes undergoing PK were as follows in Table 1.

The mean VA (in number of letters) before rejection was 48 (22 to 88 letters). Characteristics of the patients such as days of symptoms (until diagnoses and treatment), previous ocular surgical history (in our study, all surgeries were phacoemulsification), ocular pathologies, systemic diseases, corneal vascularization, epithelial defect, anterior synechia, loosen or broken sutures within 6 months of post-operative period and the presence of penetrating keratoplasty in the other eye 
Table 1

Indications for PK

\begin{tabular}{lc}
\hline Diagnosis & Number of eyes (\%) \\
\hline Fuch's distrophy & $12(37.5)$ \\
Corneal ulcer & $11(34.3)$ \\
Keratoconus & $7(21.8)$ \\
Herpetic keratitis & $1(3.1)$ \\
Steven Johnson syndrome & $1(3.1)$ \\
\hline
\end{tabular}

Table 2

Demographic data

\begin{tabular}{|c|c|c|}
\hline Demographic data & & Eyes \\
\hline \multirow[t]{2}{*}{ Eye } & Right & 19 \\
\hline & Left & 13 \\
\hline \multirow[t]{2}{*}{ Days of syntoms } & $<7$ days & 23 \\
\hline & $>7$ days & 9 \\
\hline \multirow{2}{*}{ Previous ocular surgery } & Phacoemulsification & 7 \\
\hline & No & 25 \\
\hline \multirow{5}{*}{ Ocular patology } & Glaucoma & 4 \\
\hline & Dry eye & 1 \\
\hline & Herpes & 1 \\
\hline & Trachoma & 1 \\
\hline & No & 25 \\
\hline \multirow[t]{4}{*}{ Systemic disease } & Hypertension & 3 \\
\hline & Diabetes & 6 \\
\hline & Steven Johnson & 1 \\
\hline & No & 23 \\
\hline \multirow{5}{*}{ Corneal vascularization } & 0 & 20 \\
\hline & 1 quadrant & 3 \\
\hline & 2 quadrants & 4 \\
\hline & 3 quadrants & 0 \\
\hline & 4 quadrants & 5 \\
\hline \multirow[t]{2}{*}{ Epithelial defect } & Yes & 11 \\
\hline & No & 21 \\
\hline \multirow[t]{5}{*}{ Anterior sinechia } & 0 & 24 \\
\hline & 1 quadrant & 3 \\
\hline & 2 quadrants & 4 \\
\hline & 3 quadrants & 0 \\
\hline & 4 quadrants & 1 \\
\hline \multirow[t]{2}{*}{ Loose or broken suture } & Yes & 18 \\
\hline & No & 14 \\
\hline \multirow[t]{2}{*}{ Bilateral keratoplasty } & Yes & 6 \\
\hline & No & 26 \\
\hline
\end{tabular}

were registered and showed in Table 2. Additional data were collected and graduated through record review.

\section{Outcomes}

The primary outcome measurement was the recovery of BCVA and corneal edema regression. Eight eyes from 32 did not recover previous BCVA and remained with corneal edema. The secondary outcome measurement was the development of new endothelial rejections and graft failures. 12 eyes from 32 presented new rejections, and 8 eyes from 32 were considered graft failures. By Fisher exact test, there was no statistically significant correlation between the outcomes (primary and secondary) with corneal vascularization, anterior synechia, epithelial defect and presence of loosen or broken sutures within 6 months of the surgery (Table 3). The duration of symptoms and history of previous ocular surgery showed statistically significance with the outcomes. 7 patients with more than 7 days of symptoms did not recover the previous BCVA $(\mathrm{p}<0,001)$, developed new rejections $(p<0,006)$ and graft failure $(p<0,001) .4$ patients that underwent phacoemulsification before penetrating keratoplasty did not recover the previous BCVA $(\mathrm{p}<0,047)$ and developed graft failure $(p<0,047)$. The other characteristics such as gender, eye (right or left), ocular patologies and systemic diseases did no showed any statistically significant correlation with the outcomes.

\section{Discussion}

Current practices in the management of corneal graft rejection still hold corticosteroids, in form of systemic or topical therapy, as the gold standard in the treatment of acute graft rejection and various routes of administrations have been advocated, each with their merits and demerits ${ }^{(9)}$. Systemic corticosteroids should always be administered along with topical corticosteroids. It reduces the number of circulating $\mathrm{T}$ cells and inhibit their proliferation. In our study we use a intravenous pulse therapy dose of methyl prednisolone (500 $\mathrm{mg}$ in $100 \mathrm{ml}$ of IV fluid). The aim of the treatment is to induce transient lymphopenia and gives rise to depletion of the helper cells ${ }^{(10)}$. Since the antiinflammatory effect of the pulse therapy lasts up to 7 days, we perform the second dose with one week interval. Pulse therapy is beneficial in preventing subsequent rejection episodes. Since there is no consensus about the best routes and doses of the corticosteroid treatment for corneal graft rejections, identifying the best treatment remains to be a challenging aspect in the graft survival. Conditions like corneal vascularization, anterior synechia and epithelial defect are well-known predisposing factors for graft failure and rejection reactions ${ }^{(2)}$. However our study did not find statistically association between these risk factors and the outcomes. This paradoxical observations can be due to a small

Table 3

Outcomes

\begin{tabular}{ccccccc}
\hline Outcomes & $\begin{array}{c}>\text { 7 Days } \\
\text { of syntoms }\end{array}$ & $\begin{array}{c}\text { Previous } \\
\text { surgery }\end{array}$ & $\begin{array}{c}\text { Corneal } \\
\text { vasc. }\end{array}$ & $\begin{array}{c}\text { Ant. } \\
\text { Sinechia }\end{array}$ & Epi.defect & $\begin{array}{c}\text { Loose/ } \\
\text { Broken suture }\end{array}$ \\
\hline $\begin{array}{c}\text { Without VA recovery and } \\
\text { corneal edema regression }\end{array}$ & $7(\mathrm{p}<0.001)$ & $4(\mathrm{p}>0.047)$ & $2(\mathrm{p}<0.344)$ & $3(\mathrm{p}<0.309)$ & $4(\mathrm{p}<0.256)$ & $3(\mathrm{p}<0.205)$ \\
$\begin{array}{c}\text { New rejections } \\
\text { Graft failure }\end{array}$ & $7(\mathrm{p}<0.0060$ & $4(\mathrm{p}<0.218)$ & $4(\mathrm{p}<0.503)$ & $5(\mathrm{p}<0.104)$ & $5(\mathrm{p}<0.383)$ & $6(\mathrm{p}<0.426)$ \\
\hline
\end{tabular}


sample size and short follow up. In order to find a casual relationship, a study with larger sample and longer follow-up is required. Our study showed that eyes treated within less than 7 days of symptoms presented better BVCA recovery and fewer recurrent rejections episodes (Table 3) and graft failure after the treatment with the corticosteroid. Thus it is crucial to give the patients proper education about the rejections symptoms and also offer emergency medical assistance to allow quick diagnoses and treatment of the rejection episode. Also, our case series showed that eyes submitted to phacoemulsification previously to $\mathrm{PK}$, presented poor BCVA recovery and more graft failures, suggesting that this procedure may worsen the prognostic of corneal graft survival. Clinical studies are necessary in order to investigate wether phacoemulsification or other anterior segment surgery lead to more corneal rejection or graft failure rates.

\section{CONCLUSION}

Methylprednisolone ( 2 doses of $500 \mathrm{mg}$ IV) in association with topical prednisolone is an alternative treatment for graft rejection. Our study showed that patients treated within 7 days of symptoms and no previous anterior segment surgery had better visual outcome and graft survival after treatment.

\section{REFERENCES}

1. Patel SV. Graft survival after penetrating keratoplasty. Am J Ophthalmol. 2011;151(3):397-8.

2. Williams KA, Lowe MT, Barlett CM, Kelly L, Coster DJ, editors. Australian corneal graft registry: 2007 report. Adelaide: Flinders University Press; 2007.
3. Tan DT, Janardhanan P, Zhou H, Chan YH, Htoon HM, Ang LP, et al. Penetrating keratoplasty in Asian eyes: the Singapore Corneal Transplant Study. Ophthalmology. 2008;115(6):975-82.e1.

4. Patel SV, Diehl NN, Hodge DO, Bourne WM. Donor risk factors for graft failure in a 20-year study of penetrating keratoplasty. Arch Ophthalmol. 2010;128(4):418-25.

5. Hill JC, Ivey A. Corticosteroids in corneal graft rejection: double versus single pulse therapy. Cornea. 1994;13(5):383-8.

6. Tandon R, Verma K, Chawla B, Sharma N, Titiyal JS, Kalaivani M, et al. Intravenous dexamethasone vs methylprednisolone pulse therapy in the treatment of acute endothelial graft rejection. Eye (Lond). 2009;23(3):635-9.

7. Costa DC, Castro RS, Camargo MS, Kara-Jose N. Rejeição de transplantes de córnea: tratamento tópico vs. pulsoterapia resultados de 10 anos. Arq Bras Oftalmol. 2008;71(1):57-61.

8. Krueger RR, Ramos-Esteban JC, Kanellopoulos AJ. Staged intrastromal delivery of riboflavin with UVA cross-linking in advanced bullous keratopathy: laboratory investigation and first clinical case. J Refract Surg. 2008;24(7):S730-6. Comment in J Refract Surg. 2009;25(8):687; author reply 687-8.

9. Panda A, Vanathi M, Kumar A, Dash Y, Priya S. Corneal graft rejection. Surv Ophthalmol. 2007;52(4):375-96. Review.

10. Meyer PA, Watson PG, Franks W, Dubord P. 'Pulsed' immunosuppressive therapy in the treatment of immunologically induced corneal and scleral disease. Eye (Lond). 1987;1(Pt 4):487-95. 